\title{
Salvajes y chichimecas: mitos de alteridad en las fuentes novohispanas ${ }^{1}$
}

\author{
Carlos Santamarina Novillo \\ orcid.org/0000-0002-7358-6917 \\ Departamento de Historia de América II (Antropología de América) \\ Universidad Complutense de Madrid \\ carlossn@ucm.es
}

Recibido: 29 de agosto de 2013

Aceptado: 5 de septiembre de 2014

\section{RESUMEN}

Llamamos mitos de alteridad a las creencias y el imaginario tradicionales que un pueblo proyecta en su visión etnocéntrica sobre otros pueblos. Siguiendo la propuesta de Roger Bartra, examinamos una serie de crónicas novohispanas para demostrar que los mitos de alteridad de origen europeo referentes al salvaje influyeron en las descripciones que nos han legado sobre los pueblos indígenas mesoamericanos conocidos como chichimecas. Apuntamos finalmente algunas reflexiones sobre el uso y alcance de dichos mitos de alteridad en relación con la expansión europea por América, y sobre la necesidad metodológica de someter a crítica bajo este prisma la información que nos ofrecen las fuentes disponibles, producidas, después de todo, en pleno proceso de aculturación colonial.

Palabras clave: Mitos de alteridad, crítica de fuentes, Nueva España, chichimecas, salvaje.

\section{Savages and Chichimecs: European Myths of Alterity in the Sources of New Spain}

\section{ABSTRACT}

We call myths of alterity to traditional beliefs that a people uses in its ethnocentric view over other people. Following the proposal of Roger Bartra, we examined some chronicles of New Spain to prove that European myths of alterity relating to the savage man influenced the descriptions that we have about the indigenous Mesoamerican peoples known as Chichimecs. Finally, we offer our reflections about the use and scope of these myths of alterity in relation to European expansion in America, and the methodological need of submit to criticism the information offered by the available sources. We have to remember that they was produced in the context of a global process of colonial acculturation.

Key words: Myths of alterity, Source criticism, New Spain, Chichimecs, Savage.

Sumario: 1. La caracterización del otro: etnocentrismo y mitos de alteridad. 2. El caso mesoamericano. 3. El salvaje europeo según Bartra. 4. Las descripciones de los primeros viajeros europeos. 5. Salvajes europeos en Nueva España: representaciones. 6. Los chichimecas en las crónicas novohispanas. 7. Los nombres de la alteridad. 8. Conclusiones. 9. Referencias bibliográficas.

Dedicado a Mauricio Santana

\section{La caracterización del otro: etnocentrismo y mitos de alteridad}

Todos los pueblos, de una u otra forma, tienen una idea de sí mismos, de lo que les caracteriza e identifica, de lo que constituye su cultura, de su identidad. Paralelamente, todos los pueblos tienen una idea sobre lo que les es ajeno, extraño, propio de otras

\footnotetext{
1 Sendas versiones parciales y preliminares de este trabajo fueron presentadas como ponencia en el Coloquio Internacional Formes et processus transculturels en Amérique Latine, organizado por Patrick Lesbre en la Universidad de Toulouse-Le Mirail, del 16 al 18 de marzo de 2006; y como conferencia en la Universidad Autónoma del Estado de México, organizada por René García Castro en Toluca, el 19 de noviembre de 2014.
} 
gentes: es lo que llamaremos alteridad, es decir, la concepción que los integrantes de una sociedad o cultura tienen de los que no pertenecen a ella, de los que pertenecen a otra, o, como dice sencillamente el diccionario de la Real Academia, de los que ostentan la «condición de ser otro» (DRAE, sub voce).

Por otro lado, todos los pueblos tienden a considerar adecuado y normal, e incluso legítimo y natural, aquello que les es propio culturalmente, mientras que verterán los calificativos opuestos sobre lo que les sea culturalmente extraño: en el caso más extremo, será considerado contra-natura, inhumano o demoníaco. Esa tendencia universal, que denominamos etnocentrismo, es un fundamento básico y primario en la consideración que cualquier grupo humano tiene sobre los otros, sobre los que no pertenecen a su propia cultura. En palabras de Lévi-Strauss:

«Un gran número de tribus primitivas se nombran con una denominación que, en su lenguaje, sólo significa 'los hombres', lo que demuestra que, para ellos, cuando se sale de los límites del grupo desaparece un atributo esencial de la humanidad» (LéviStrauss 1969: 46) ${ }^{2}$.

En consecuencia, para afirmar su propia identidad, con frecuencia los pueblos elaboran una serie de prejuicios, creencias y en general representaciones sesgadas desde un punto de vista etnocéntrico sobre los otros pueblos. Nosotros denominaremos aquí mitos de alteridad a esa serie de elaboraciones ideológicas altamente subjetivas que los integrantes de una cultura proyectan sobre otras culturas. Pueden y deben considerarse una expresión de etnocentrismo, y dentro de esa categoría podemos encontrar desde simples estereotipos a corrientes ideológicas mucho más sutiles, profundas y complejas. Hay que precisar, además, que los mitos de alteridad no surgen necesariamente de la observación, del contacto de un pueblo con otros pueblos, sino que con frecuencia preceden a ese contacto y nacen y se desarrollan en lo que podríamos llamar el imaginario cultural de un pueblo, incluyendo por tanto multitud de elementos fantásticos y de ficción.

En el caso frecuente en que contamos con descripciones que un pueblo hace sobre otro, el conocimiento de los mitos de alteridad de la cultura observadora será fundamental para interpretar su discurso, que posiblemente estará impregnado, consciente e inconscientemente, de todo ese bagaje cultural en el sentido más amplio de aquellos que ocupan la posición de observadores. No podemos, pues, reconocer valor etnográfico a esa información indirecta sin reparar en la carga de etnocentrismo que arrastra, en los mitos de alteridad que impregnan una descripción a la cual, por definición, debemos examinar desde una distancia crítica. Precisamente, el análisis e interpretación de este tipo de testimonios, que forma parte de lo que los historiadores suelen denominar crítica de fuentes, se ha de fundamentar en la consideración compleja de los mitos de alteridad que median entre la cultura observadora y la observada, para, reconociéndolos, determinar su influencia y distinguirlos de la información que podamos considerar veraz.

El estudio de los mitos de alteridad plantea además dos grandes temas de interés. Por un lado, conocerlos permitirá profundizar en la historia, creencias, ideología y cosmovisión de la cultura que los genera; por otro, su conocimiento nos ayudará a

2 Véase también Levi-Strauss 1996: 99 y Todorov 1992: 84. 
depurar la información que se nos proporciona sobre otros pueblos. Por último, el tema propuesto tiene además el interés de tener visos de universalidad, pues los mitos de alteridad son una proyección ideológica del etnocentrismo presente, en principio, en todas las culturas ${ }^{3}$.

\section{El caso mesoamericano}

Cuando nos dedicamos a investigar la historia y cultura mesoamericana prehispánica nos vemos obligados a utilizar fuentes que, en su práctica totalidad, fueron elaboradas, cuando tempranas, en el siglo XVI, ya en marcha el proceso global de cambio cultural impuesto por los españoles, es decir, en pleno proceso de aculturación.

Tal escenario de trabajo requiere ante todo dos consideraciones preliminares. Por un lado, hemos de tener en cuenta que la sociedad prehispánica deja de existir por definición cuando los españoles llevan a cabo la conquista: desde ese momento hablaremos de culturas indígenas, con una continuidad más o menos acusada, según los casos, con el periodo prehispánico. Por muy evidente que pueda parecer esa continuidad entre un periodo y otro, es algo que en todo caso habrá de investigarse, siempre sin minimizar el proceso global de cambio desatado por el establecimiento europeo en América.

Por otro lado, las fuentes que manejamos para conocer las culturas indígenas prehispánicas, fueron elaboradas, en su inmensa mayoría, por españoles, mestizos o indígenas, pero en cualquier caso todos ellos integrantes de la cultura hispana dominante, educados en instituciones creadas por los españoles en el ámbito de la religión y la tradición cultural hispanas. Escribían a veces en castellano, otras en latín, y otras veces en una lengua indígena como el náhuatl, pero mediante caracteres alfabéticos europeos ${ }^{4}$.

Hemos pues de tener en cuenta la complejidad del periodo colonial temprano, donde confluyen tan numerosas y diversas influencias culturales, siempre dentro de un sistema de dominación colonial. Todo ello nos obliga a someter nuestras fuentes a un proceso crítico de deconstrucción, con el objeto de separar en lo posible la información de origen auténticamente prehispánico de las influencias y añadidos procedentes de la cultura novohispana dominante, es decir, de la cristiana.

Una de esas influencias de origen europeo consistirá en esos mitos de alteridad que proponemos como concepto para el análisis. Nuestro propósito aquí, en consecuencia, va a consistir en determinar hasta dónde llega el sesgo etnocéntrico que aportan dichos mitos de alteridad de origen europeo en las descripciones sobre los pueblos indígenas. Nos serviremos para ello de una propuesta del antropólogo mexicano Roger Bartra (1992), que ha descrito el mito europeo del salvaje u homo silvestris, para sondear su posible influencia sobre las descripciones que nos presentan las fuentes de

\footnotetext{
3 Óscar Muñoz Morán (2008) ha reflexionado sobre algunos términos de alteridad vigentes en el México actual. Un interesante campo de estudio donde se refleja el problema es el de la etnonimia: de cómo los pueblos se designan a sí mismos y a los otros. Véase el comentario de Moore (2004: 27-28) refiriéndose al caso de cheyennes y dakotas, etnias indígenas norteamericanas.

4 Toda traducción - entre dos lenguas y entre dos culturas-implica una distorsión del mensaje, y da ocasión a que las categorías de la cultura receptora se impongan a las de la cultura emisora. En el caso que nos ocupa hemos de considerar además que el paso al texto alfabético del mensaje oral tradicional indígena, en su caso con ayuda de documentos pictoglíficos, constituye un factor añadido de distorsión (Santamarina 2006: 184).
} 
algunos grupos indígenas mesoamericanos de cultura menos compleja, generalmente conocidos como chichimecas.

La hipótesis de trabajo consiste pues en que el mito tradicional europeo del salvaje influyó en las descripciones novohispanas que se hicieron de los chichimecas, las cuales acusarían, por lo tanto, rasgos provenientes del imaginario europeo y no de la realidad indígena americana.

\section{El salvaje europeo según Bartra}

La tesis principal de Bartra es la siguiente:

«la cultura europea generó una idea del hombre salvaje mucho antes de la gran expansión colonial, idea modelada en forma independiente del contacto con grupos humanos extraños de otros continentes. Quiero, además demostrar que los hombres salvajes son una invención europea que obedece esencialmente a la naturaleza interna de la cultura occidental. Dicho en forma abrupta: el salvaje es un hombre europeo, y la noción de salvajismo fue aplicada a pueblos no europeos como una transposición de un mito perfectamente estructurado cuya naturaleza sólo se puede entender como parte de la evolución de la cultura occidental» (Bartra 1992: 16).

Es decir, que el mito o estereotipo europeo del salvaje no procede de los contactos con otras culturas, sino que se trata de una tradición literaria e iconográfica que se remonta a los orígenes de Europa, en las culturas mesopotámica, hebrea, griega o celta, que se fue diversificando y enriqueciendo a través de la Edad Media y que estaba pues presente en la mentalidad dominante en la Nueva España del siglo XVI. Más importante para nuestros fines es la afirmación final de Bartra, en el sentido de que ese mito preexistente del salvaje se proyectó sobre los pueblos afectados por la expansión colonial europea. De este modo, el mito del salvaje acompañó al europeo en su expansión por el nuevo continente, pues formaba parte de su bagaje ideológico y cultural, y como tal, se instaló en América para quedarse.

Si bien es cierto que en el mundo mítico del salvaje hay una gran cantidad de variantes y derivados, las llamadas similitudes hominis, que incluyeron a faunos, silenos, centauros, ninfas, gigantes, sirenas, pigmeos o sátiros, entre muchos otros, nosotros procuraremos aquí caracterizar brevemente al homo silvestris con vistas a poder detectar su presencia en nuestras fuentes.

El salvaje medieval, según Bartra (1992: 136):

«presenta un tipo físico definidamente humano, con características raciales similares a las de la población europea. Un rasgo notable, sin embargo, lo alejaba de la especie humana: tanto los machos como las hembras ostentaban un cuerpo profusamente velludo; su piel era como la de un oso o la de un lobo. El pelo les cubría todo el cuerpo salvo el rostro, las manos y los pies, y los codos y las rodillas. Por lo demás, solían ser hombres blancos y barbados, con una abundante cabellera ondulada, la piel clara, los labios delgados y la nariz estrecha».

Para Alberto Magno (1206-1280), los bárbaros eran «aquellos que no observan las leyes», y por tanto confunden y destruyen las relaciones sociales basadas en principios de justicia: 
«Cicerón, al principio de De inventione los llama 'hombres salvajes que llevan la vida de animales con las bestias salvajes'... O, de la misma forma, hombres bestiales que comen carne cruda y beben sangre, y a quienes les gusta beber y comer en calaveras humanas» (Pagden 1988: 42).

Vemos en este texto cómo la caracterización del salvaje es antigua y va pasando a través de las generaciones: en este pasaje desde la antigüedad romana a la Edad Media, recogido en el discurso de grandes autoridades intelectuales, convirtiéndose en una tradición europea de origen ancestral y largo alcance.

Resumiremos entonces las características del salvaje tal y como las presenta el antropólogo mexicano (Bartra 1992: 81-116):

1) Cuerpo humano de tipo europeo, de hombre o mujer, pero completamente cubierto de vello y con fuerza sobrehumana.

2) Habitante de montes y bosques, lejos de ciudades.

3) Asociado a la Naturaleza - semibestial- frente a la Cultura y Civilización.

4) Vive a la intemperie y en soledad.

5) Está a merced de sus impulsos naturales, que no están contenidos por la razón, por lo que agrede violenta y sexualmente a los viajeros.

6) Come sin transformar lo que toma de la naturaleza: sin uso del fuego, todo crudo.

7) Sin forma de gobierno, sin normas sociales.

8) Sin alma ni razón (sin religión ni inteligencia superior).

9) Sin lenguaje inteligible, sin capacidad de comunicación social.

Es evidente que se trata de un retrato en negativo de lo que se considera el «hombre civilizado». El salvaje se caracteriza por la carencia de una serie de atributos que se consideran definitorios de lo humano, y que tienen que ver con la comunicación, con la vida social, con la complejidad cultural.

La conformación del mito en la cultura occidental viene a establecer la característica oposición ideológica europea entre barbarie y civilización, campo y ciudad, instinto y razón, paganismo y cristianismo, y, en definitiva, mal y bien ${ }^{5}$.

\section{Las descripciones de los primeros viajeros europeos}

Antes de entrar a considerar las crónicas novohispanas, hemos de mencionar los antecedentes de la expansión europea, cuando viajeros y descubridores ofrecían descripciones que acusaban una gran carga mitológica.

Durante la Edad Media, se buscaba explicar el mundo más desde la religión cristiana que explorando empíricamente otros paisajes y otros pueblos. La mentalidad dominante no invitaba a la búsqueda en el mundo real, sino que más bien utilizaba

5 Se diría que el mito del salvaje viene a dar forma explícita a los miedos que habitan en la oscuridad de la mente humana, siempre dentro de un contexto cultural determinado aunque dinámico a lo largo de la historia; representa lo que el hombre virtuoso debe rechazar, al mismo tiempo que implícitamente reconoce que forma parte de sí mismo, como el Mr. Hyde de Robert Louis Stevenson, el cual, sin duda, es una de las más logradas revisiones literarias modernas del mito tradicional europeo del salvaje. 
lo lejano y desconocido para establecer el contraste maniqueo entre lo normal, apropiado, conocido y cercano, y lo extraño, lejano y monstruoso. Como expresó Delacampagne, «las monstruosas criaturas de tierras ignotas se constituían en metáfora y signo de lo demoníaco» (Bestard y Contreras 1987: 71).

Así que los viajeros de finales del siglo XV o del XVI que se atrevieron a aventurarse por tierras desconocidas para descubrir y explorar, llevaban consigo un bagaje ideológico, fantástico y mitológico, plagado de hombres salvajes, gigantescos o enanos, a veces con cuerpos semihumanos, de un solo ojo, o acéfalos con el rostro en el pecho, en otras ocasiones mezcla de otros animales, y con alguna frecuencia temibles comedores de carne humana. Pero también les impulsaba la esperanza de encontrar ciudades maravillosas llenas de oro, o la fuente de la eterna juventud, o lugares donde no se envejecía, cuando no directamente el paraíso terrenal ${ }^{6}$.

Tal y como ha escrito Anthony Pagden...

«Antes de 1492 [los espacios imaginarios de los hombres europeos] habían estado ocupados en gran parte por fenómenos naturales fantásticos extraídos de la literatura imaginativa de la Baja Edad Media. Muchos de éstos, en particular los antropológicos - los faunos y los sátiros, los pigmeos, los caníbales y las amazonas- provenían inicialmente de una tradición oral popular y, posteriormente, aparecían como seres reales en las obras de científicos naturales y de escritores de viajes, desde Plinio a John de Mandeville. Para muchos europeos de los últimos siglos de la Edad Media constituían un 'aparato' mental, un conjunto de imágenes que, según ellos, formaban un mundo natural real en las áreas más remotas del mundo [...]: los viajeros del siglo XVI fueron a América con ideas precisas de lo que podían encontrar allí. Fueron buscando hombres salvajes y gigantes, amazonas y pigmeos [...] caníbales y hombres que vivían más de cien años» (Pagden 1988: 29-30) ${ }^{7}$.

Sin embargo, el descubrimiento, conquista y colonización de América cambiará el panorama, sobre todo por lo que respecta a los españoles, o a los europeos que se asentaron en el nuevo mundo, pues diariamente vivían el contraste de aquellas tierras, y de las diferentes culturas indígenas, con su mundo de origen. Por ello, una cuestión crucial que hemos de plantearnos en este momento es hasta qué punto los mitos de alteridad tradicionales sobrevivieron a esa convivencia.

Bestard y Contreras engloban a cronistas españoles asentados en América, como Bernardino de Sahagún o Bernal Díaz, con otros escritores de viajes europeos como Bry, Ramusio o Raleigh, para afirmar que...

«estos textos [...] ofrecen documentos concretos y precisos junto a consideraciones que se corresponden con los presupuestos mitológicos y teológicos herederos de la Edad Media» (Bestard y Contreras 1987: 78).

\footnotetext{
6 No podemos detenernos aquí a ampliar este apasionante panorama imaginario que ha llenado la cultura literaria europea de variantes del hombre salvaje. Baste como muestra recordar los relatos tradicionales referentes a grandes viajeros, como Gulliver, Simbad, o el propio Ulises, para reparar en la riqueza y amplitud del universo imaginario del hombre salvaje que puebla la tradición literaria occidental y por lo tanto acompaña al europeo en sus viajes a través de la geografía, la historia, y la diversidad cultural.

7 Y, como veremos, el observador suele ver lo que espera ver. Así se explica el que el propio Colón afirme haber visto $-\mathrm{y}$ en diversas ocasiones- sirenas, aunque «no eran tan hermosas como las pintan, que en alguna manera tenían forma de hombre en la cara» (Colón 1991: 124, día 9 de enero de 1493).
} 
En principio nos parece desafortunado amalgamar a los citados cronistas españoles, que vivieron la mayor parte de su vida en América, trabajaron sobre el terreno, estudiaron las lenguas indígenas y son autores de obras muy valiosas para conocer la historia y la cultura mesoamericana, con autores europeos como los citados, que nunca llegaron a conocer tan directamente la realidad americana y en su mayoría escribían desde y para la lejana Europa. Eso significa que encontramos una mayor carga fantástica, literaria y etnocéntrica, y por lo tanto menor realismo, en dichos autores europeos y que sus descripciones carecen de todo valor etnográfico. Sin embargo, ello no descarta, evidentemente, la presencia de los mitos de alteridad europeos en los cronistas. Bastará una cita del relato que ofrece Bernal Díaz del Castillo sobre la entrada de los españoles en Tenochtitlan, capital azteca ${ }^{8}$, para subrayar la presencia del imaginario literario en la mente de los primeros españoles que se asentaron en América:

«...desde que vimos tantas ciudades y villas pobladas en el agua, y en tierra firme otras grandes poblaciones, y aquella calzada tan derecha por nivel como iba a México, nos quedamos admirados, y decíamos que parecía a las cosas y encantamientos que cuentan en el libro de Amadís, por las grandes torres y cues y edificios que tenían dentro en el agua, y todas de cal y canto; y aún algunos de nuestros soldados decían que si aquello que veían si era entre sueños» (Díaz del Castillo 1982, cap. LXXXVII: 175-176)9 .

Valga el texto del lugarteniente de Cortés como muestra tanto de la vocación realista de la descripción como de la presencia del imaginario europeo en las mentes de los observadores españoles, así como de transición hacia nuestro estudio propiamente dicho sobre los textos de los cronistas.

\section{Salvajes europeos en Nueva España: representaciones}

Como primer paso, podemos constatar la presencia, no ya mental sino material, del salvaje europeo en la América colonial temprana reconociéndolo como representación artística trasplantada por los españoles. Recurriremos de nuevo al soldado cronista medinense.

En 1538, en el marco de una serie de festejos para celebrar la paz con Francia, tuvo lugar en la Plaza Mayor de México una representación que incluía un escenario boscoso o silvestre. Tal y como describe el propio Bernal:

8 Utilizamos el gentilicio azteca en sentido genérico para referirnos a la cultura prehispánica predominantemente de habla náhuatl, políticamente establecida en el periodo posclásico tardío en forma de imperio hegemónico con capital en Tenochtitlan, centro de la etnia mexica (Santamarina 2006: 24-27).

9 Otros muchos casos ponen de manifiesto la influencia del imaginario europeo a la hora, por ejemplo, de poner etnónimos o topónimos a los pueblos y tierras que descubren: las amazonas (Bartra 1992: 22) o el gigante Patagón -personaje de Primaleón, un libro de caballerías publicado en Salamanca en 1512 (Marín 1998) - son variantes del amplio, diacrónico y diverso mito del salvaje que sirvieron de inspiración para tal fin. El gigante como variante del hombre salvaje con «presencia» en la Nueva España no ha tenido cabida en este artículo exclusivamente por razones de espacio, pero sin duda presenta interesantes posibilidades como tema de estudio desde la perspectiva que aquí proponemos y como tal será objeto de una posterior publicación. 


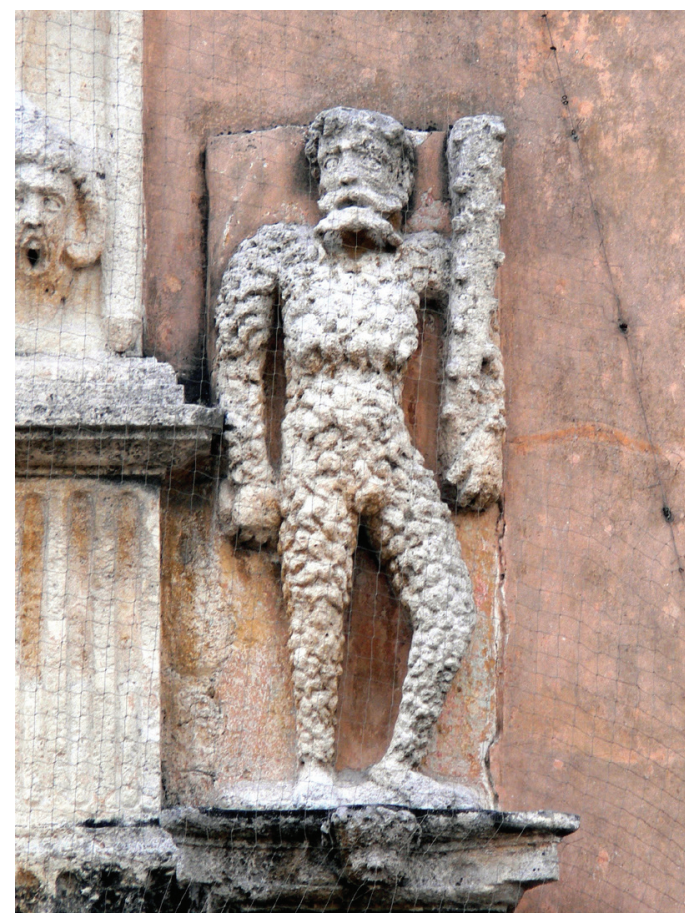

Figura 1: Imagen de uno de los salvajes esculpidos en la facha de la Casa de Montejo, en Mérida, Yucatán (fotografía de Wolfgang Sauber).

«...había otras arboledas muy espesas algo apartadas del bosque, y en cada una de ellas un escuadrón de salvajes con sus garrotes añudados y retuertos, y otros salvajes con arcos y flechas; y vanse a la caza; [...] y salen a la plaza mayor, sobre matar la caza, los unos salvajes con otros revuelven una cuestión soberbia entre ellos, que fue harta de ver cómo batallaban a pie; y desde que hubieron peleado un rato se volvieron a su arboleda» (Díaz del Castillo 1982, cap. CCI: 608).

Los salvajes, importados de Europa, van armados con recios garrotes, como el palo de bastos de la baraja española, el cual constituye otro de los atributos más reconocibles en el estereotipo del salvaje europeo.

El mismo garrote aparece también en otra representación del salvaje europeo en Nueva España. Se trata de la fachada de la casa de Francisco de Montejo, conquistador de Yucatán, en Mérida (Figura 1). Allí tenemos sendos salvajes esculpidos en piedra, similares a los que pueden encontrarse en otros edificios históricos en España ${ }^{10}$. No estamos ante una representación de los indígenas mayas vencidos por Montejo, como algún observador ha llegado erróneamente a interpretar, sino que, muy al contrario, se trata de un motivo iconográfico y literario tradicional europeo trasplantado a tierras americanas por los españoles (Bartra 1992: 13).

Pasando ahora a documentos escritos en Nueva España en la etapa colonial, nos acercaremos a una de las principales fuentes con que contamos para el conocimiento de la cultura azteca, la Historia de las cosas de la Nueva España, escrita por el domi-

10 Entre otros ejemplos, baste citar la fachada del Colegio de San Gregorio en Valladolid, la llamada Casa de los Salvajes en Cadalso de los Vidrios, Madrid, o la fachada occidental de la Catedral de Ávila. 


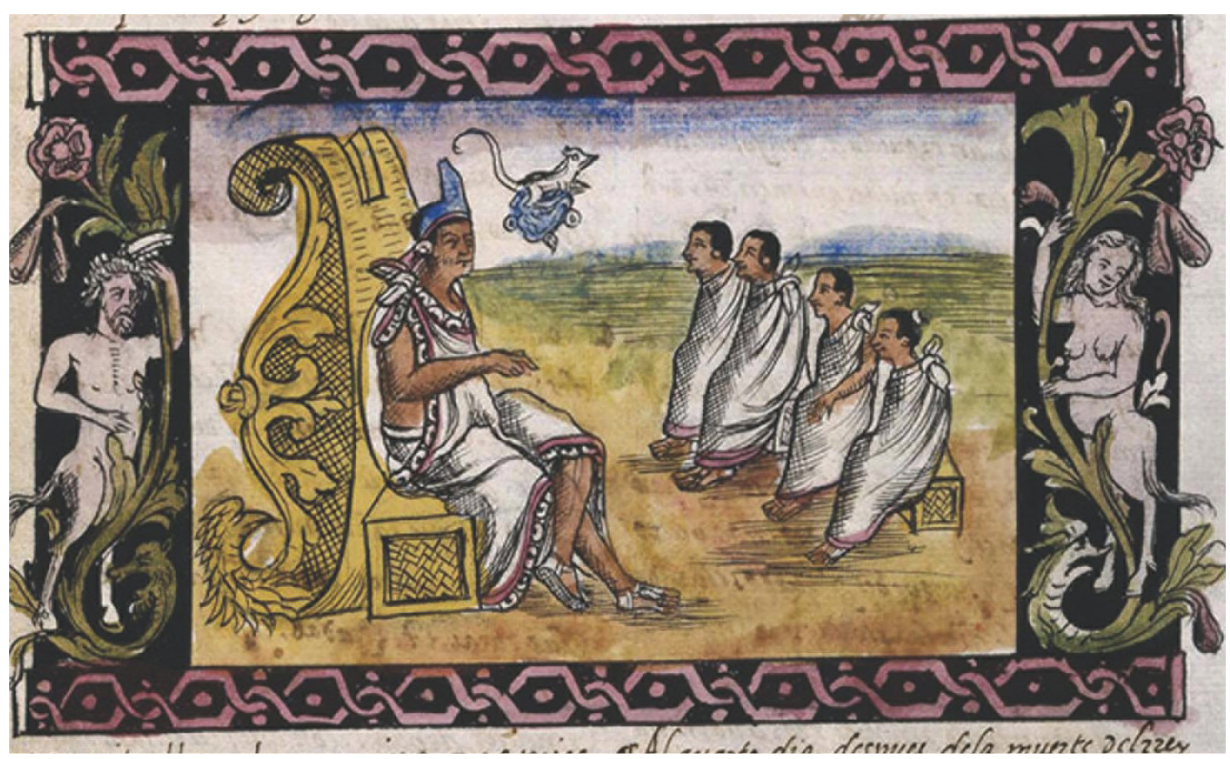

Figura 2: Códice Durán, fol. 118v. Faunos decorativos.

nico Diego Durán en el último tercio del siglo XVI, también conocida como Códice Durán. Está compuesta a partir de fuentes indígenas anteriores, por lo que traslada la tradición mexica-tenochca. Esta obra presenta además un amplio contenido gráfico. Hemos de distinguir, sin embargo, entre dos tipos de imágenes presentes en el Códice Durán. El primero se refiere a las imágenes que ilustran la historia tenochca que el texto alfabético relata; el segundo, las imágenes presentes en las cenefas laterales que las enmarcan con fines decorativos. En estas cenefas, además de motivos vegetales o geométricos, encontramos una serie de faunos de ambos sexos que, con su cuerpo humano hasta la cintura y cabrío en sus cuartos traseros, nos presentan una conocida variante del complejo mitológico del salvaje europeo (Figura 2$)^{11}$.

A la luz de los tres ejemplos citados hasta ahora, constatamos la presencia de la iconografía del salvaje trasplantada desde Europa por los españoles. Pero en ninguno de estos casos está expresando una alteridad que pudiera identificarse con las culturas indígenas americanas, sino que se trata de representaciones artísticas o decorativas tradicionales propias de la cultura dominante que, como tales, se instauran y difunden en la sociedad colonial.

Pero si seguimos examinando el Códice Durán encontraremos otras imágenes que sí pretenden ilustrar la historia y cultura tenochca que hemos mencionado antes en primer lugar. Claramente se advierte la influencia europea, pero al mismo tiempo se deja ver que sin duda están también basadas en fuentes pictográficas indígenas anteriores. Pues bien, entre estas imágenes, en el folio 131r, encontramos la repre-

11 Durán 1984, tomo II, figura 28, folio 118v en el original: puede consultarse en versión digitalizada en la Biblioteca Digital Hispánica perteneciente a la Biblioteca Nacional de España: http://bdh.bne.es, PID 1897725. 


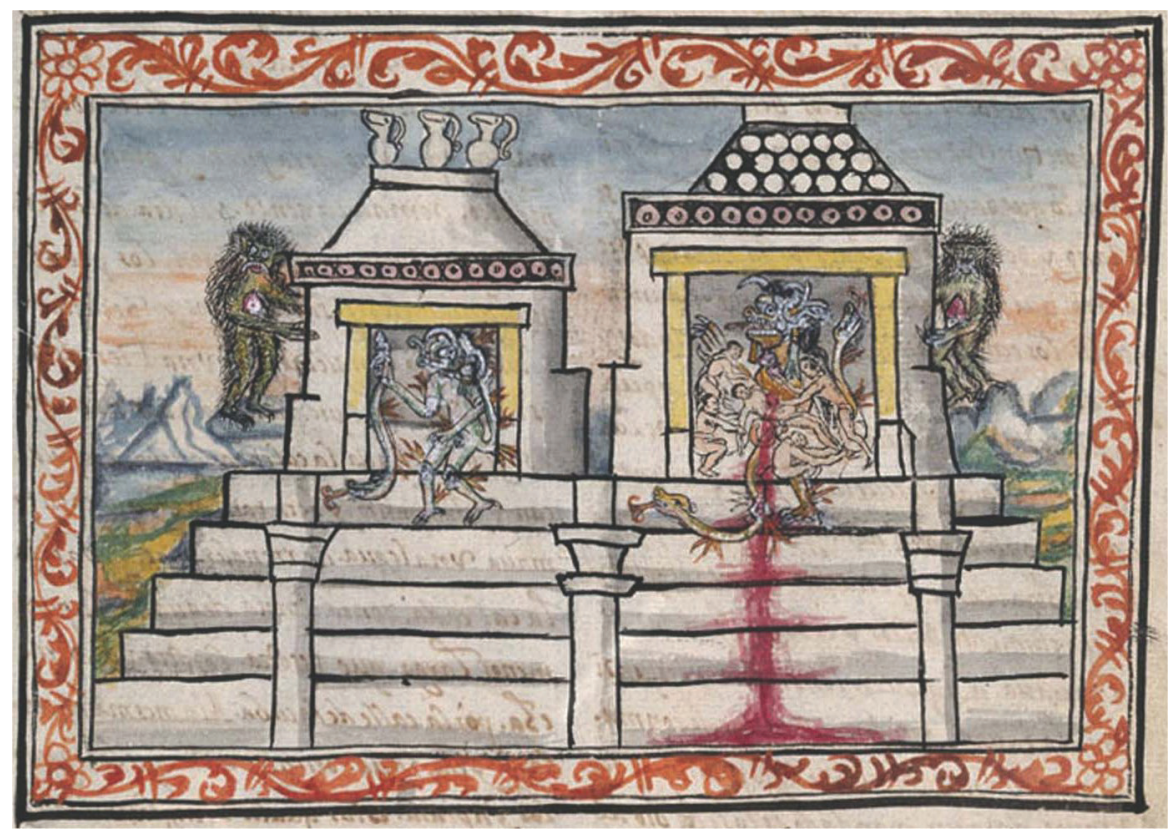

Figura 3: Códice Durán, fol. 131r. Salvajes peludos en el Templo Mayor como representación de lo demoníaco de la religión azteca.

sentación de una doble escalinata coronada por sendos templos (Figura 3) ${ }^{12}$. En cada uno de ellos figura una deidad azteca y, en el templo de la derecha, un sacerdote está llevando a cabo un sacrificio humano por extracción del corazón. Pero nuestro interés ha de centrarse en las dos figuras simétricas que parecen levitar a ambos lados del templo doble. Si el resto de la imagen es reconocible como versión colonial de pictografías aztecas prehispánicas, incluyendo las representaciones de las deidades, ahora nos encontramos con una figura antropomorfa, con todo el cuerpo recubierto de pelo y grandes garras tanto en pies como en manos. Puesto que en el texto no hay referencias a estas inquietantes figuras, nuestra interpretación es que el pintor colonial, que trabajaba a partir de pictografías indígenas incluidas seguramente en las fuentes que maneja Durán para componer su Historia $\ldots{ }^{13}$ quiso reproducir, para mejor comprensión del público europeo, estos dos demonios peludos con objeto de expresar el significado diabólico que se otorga a las deidades indígenas y, muy en particular, a los ritos sacrificiales. La occidentalización de las imágenes es claramente reconocible, además, en la profusión de sangre chorreante con que se representa el sacrificio humano, un rasgo iconográfico impuesto por los observadores españoles

12 Durán 1984, tomo II, figura 30 (folio 131r en el original). La imagen incluida en el Códice Durán ha de representar el Templo Mayor de Tenochtitlan (Durán 1984, tomo II, cap. XLIV: 345), que sabemos estaba dedicado al dios patrono mexica Huitzilopochtli y a Tlaloc, dios del agua.

13 Durán trabaja reproduciendo una fuente hoy perdida conocida como Crónica X. De ella podemos deducir, además de que era más antigua, que había sido escrita en náhuatl y que contenía pictografías, siendo por lo tanto una reproducción más fiel a la cultura azteca y menos occidentalizada que sus derivados (Barlow 1990). 
para hacer explícito y evidente el horror de aquel ritual. Tanto la sangre chorreante como el cuerpo completamente cubierto de pelo son rasgos claramente occidentales y del todo ajenos a la tradición indígena (Batalla 1994: 49). Es en este contexto donde se manifiesta el bagaje ideológico compartido por el pintor y los religiosos que encargaron, dirigieron y censuraron su trabajo: ahora sí encontramos una expresión de alteridad, pues las deidades extranjeras se asocian al maligno, y su representación se nos hace reconocible en esas formas monstruosamente semihumanas, como una realización más de las que emanan de la tradición del salvaje europeo.

Además, el caso nos muestra cómo la traslación -en el sentido más amplio- de los significados tradicionales aztecas al contexto colonial, conlleva el trastoque de las categorías culturales utilizadas para representar ciertos rasgos sensibles a ese tránsito. Lo que era una deidad prehispánica pasa a asociarse a crueldad demoníaca, y así las connotaciones del templo y del rito cambian por completo ${ }^{14}$.

\section{Los chichimecas en las crónicas novohispanas}

Aunque el término chichimeca se usa en las fuentes novohispanas en diferentes sentidos, y carece de un significado étnico concreto (Soustelle 1993: 458-460), básicamente viene a caracterizar a pueblos de cultura menos compleja y refinada, pueblos nómadas inmigrantes desde el norte que contrastan con los descendientes de los toltecas, representantes y herederos de la alta cultura mesoamericana. En las fuentes indígenas, tal contraste toma un cariz ideológico, estableciéndose una «oposición entre dos categorías culturales: la chichimecayotl y la toltecayotl, la calidad de nómadas y sedentarios, la barbarie y la civilización» (López Austin y López Luján 1999: 65). Se construye así una concepción ideológica de alteridad, con la cual los mexicas, que se definen a sí mismos como toltecas - culhuas-, pretenden resaltar su superioridad histórica y cultural, que les legitima para ostentar el poder político ${ }^{15}$.

Por nuestra parte nos interesa aquí revisar las descripciones que nos ofrecen las fuentes novohispanas sobre los chichimecas, como pueblos de cultura cazadora y recolectora, para tratar de determinar su posible valor etnográfico y detectar en su caso la posible influencia de los mitos de alteridad europeos.

Empezaremos con Francisco López de Gómara, que fue capellán de Cortés, y publicó en 1552 su obra La Conquista de México. Allí dedica un epígrafe a los chichi-

14 Podemos ofrecer otros dos claros ejemplos del mismo proceso. El primero lo tenemos en el topónimo Tlallocan, morada de Tlalloc, dios del agua y de la tierra según las creencias mesoamericanas, el cual es interpretado por Sahagún como Paraíso (Contel 2000). El segundo se refiere al término náhuatl tlacatecolotl -hombre-búho- que en la sociedad azteca designaba a cierto tipo de sacerdote. La traducción de dicho término al castellano como «diablo» (Molina 1992: sub voce) reduce maniqueamente el significado del término, que hasta hoy permanece oscuro para nosotros. Sahagún, de hecho, reparó en esta circunstancia, considerando la traducción impropia, pero su alternativa de «nigromántico o brujo» no nos aporta mucho más (Anales de Cuauhtitlan en Códice Chimalpopoca 1992, §152: 40 y 95).

15 Tal oposición no es óbice, sin embargo, para la existencia de otra variante con el mismo fin legitimador. En ocasiones ciertos pueblos aztecas -incluidos los propios mexicas- se autodenominan chichimecas para resaltar sus méritos históricos como pueblo guerrero «hecho a sí mismo», pues a partir de unos orígenes humildes habían sabido establecerse como potencia política en el área, digna heredera del antiguo imperio tolteca (Santamarina 2006: 111-112). 
mecas, aunque fundamentalmente lo hace refiriéndose a los chichimecas históricos, antepasados de los acolhuas entre otros pueblos del área central mesoamericana a la llegada de los españoles:

«No tenían rey cuando entraron aquí; no hacían pueblo, ni aun casa; moraban en cuevas y por los montes, andaban desnudos, no sembraban, no comían maíz ni otras semillas, ni pan de ninguna clase; se mantenían de raíces, hierbas y frutas del campo; y como eran muy diestros en tirar al arco, mataban muchos venados, liebres, conejos y otros animales y aves, y comían toda esta caza, no guisada, sino cruda y seca al Sol; también comían culebras, lagartos y otras sabandijas así, sucias, asquerosas y fieras, y aun hoy día hay muchos de ellos allá en su naturaleza que viven así. Siendo, sin embargo, tan bárbaros y viviendo vida tan bestial, eran hombres religiosos y devotos; adoraban al Sol, le ofrecían culebras, lagartijas y animalejos semejantes [...]; eran feroces y belicosos, por cuya causa señorearon la tierra» (López de Gómara 1987: 424) ${ }^{16}$.

Vemos aplicadas en la descripción algunas de las características definitorias del salvaje, que se conciben como muestras de carencia de civilización: falta de monarquía, de sedentarismo, de agricultura y de transformación del alimento, así como de repugnancia -máxima expresión de identidad cultural en lo culinario- ante ciertos animales utilizados como alimento. Por otro lado, se presenta la naturaleza -y más en concreto, los montes- como su entorno de vida, calificándolos de bárbaros, bestiales $\mathrm{y}$ feroces.

Retomemos la Historia de las Indias ... de Diego Durán, aunque ahora para dirigirnos al texto de la obra. Allí encontramos la siguiente descripción:

«La gente que vivía de esta parte era muy poca, cuyo modo era brutal y salvajino, a quien esta nación llamó chichimeca, que quiere decir 'cazadores, o gente que vive de aquel oficio', agreste y campesina. Llamáronlos de esta manera a causa (de) que ellos vivían en los riscos y en los más ásperos lugares del monte, donde vivían una vida bestial, sin ninguna pulicía ni consideración humana, buscando la comida como las bestias del mesmo monte, desnudos en cueros, sin ninguna cobertura de sus partes verendas, andando todo el día a caza de conejos, venados, liebres, comadrejas, topos, gatos monteses, pájaros, culebras, lagartijas, ratones, langostas, gusanos y hierbas, raíces, con lo cual se sustentaban y toda la vida se les iba en esto y en andar a caza de estas cosas.

[...] Dormían en los montes debajo de las cuevas, debajo de los matorrales, sin ningún cuidado de coger, ni sembrar, ni cultivar, no dándoles pena el día de mañana, comiendo lo que aquel día habían cazado, y así acudían al monte a buscar qué comer ellos y ellas, como el perro al muladar, donde con instinto natural halla qué roer.

[...] Estos chichimecas eran tan pocos y tan apartados unos de otros, que no tenían entre sí ninguna conversación. No adoraban dioses ningunos, ni (tenían) rito de ningún género, ni tampoco tenían ni conocían superior. Vivían en solo ley natural, sin cuidado de cosa que pena les diese» (Durán 1984, II: 24).

16 La información etnográfica de este autor procede de la obra de Motolinía, cuya descripción es por tanto muy semejante a la citada. Dice que los chichimecas eran «gente bárbara y que vivían como salvajes» (Motolinía 1985: 54). 
Como etnohistoriadores, es decir, como antropólogos que estudian las culturas indígenas en la historia, hemos de preguntarnos en primer lugar por el posible valor etnográfico del texto, en cuanto descripción de la cultura de estos pueblos denominados chichimecas. Para ello, necesariamente manejaremos el modelo de aquellas sociedades no estratificadas o igualitarias, cuyo modo de subsistencia es la caza y recolección, viven en bandas poco numerosas de forma nómada, no han desarrollado instituciones estables de gobierno y no practican la agricultura ni la vida urbana. Puede entenderse, efectivamente, que ese es el tipo de cultura que el dominico está describiendo, sin embargo y a todas luces, en esa descripción -como en la anterior de López de Gómara- encontramos una serie de componentes subjetivos que claramente pretenden establecer la inferioridad del modo de vida chichimeca respecto a la cultura del observador, dejando traslucir la influencia de los mitos de alteridad importados por los europeos.

Efectivamente, encontramos en la descripción una serie de rasgos a los cuales no podemos conceder historicidad, valor de verdad histórica, puesto que reconocemos, muy claramente reproducidos, los argumentos que hemos establecido como propios de ese ser imaginario tradicional europeo, el homo silvestris: viven de modo brutal y salvajino, son agrestes, como bestias, como perros; viven en riscos y ásperos montes, sin policía -sin organización política y social-, desnudos sin pudor y sin más oficio que la caza; carecen de viviendas, de agricultura; son escasos en número, no forman sociedades populosas ni urbanas, no conversan entre ellos; carecen de religión y de ritos, así como de jerarquías de mando, viven en estado de naturaleza, bajo la «ley natural».

A la luz de los conocimientos acumulados por la antropología, los rasgos que se han señalado no describen a ninguna sociedad humana, por simple o primitiva que sea: incluso la menos compleja de las bandas de cazadores recolectores tiene lenguaje, rituales, creencias, organización social y política, y elabora recursos habitacionales o de vestimenta. Es pues evidente que la descripción del observador está profundamente impregnada de esos mitos de alteridad referentes al salvaje, que establece un claro contraste entre la cultura cristiana, urbana y agrícola y la vida chichimeca, el cual, evidentemente, constituye un argumento legitimador de la dominación, de la aculturación y de la evangelización, y en su caso del desplazamiento o exterminio.

Otros ejemplos en las crónicas corroboran la interpretación anterior. Un manuscrito escrito entre 1571 y 1585 por un religioso llamado Gonzalo de las Casas, da noticia de la expresión chichimeca en los siguientes términos:

«Este nombre chichimeca es generico, puesto por lo mexicanos (en ignomia) a todos los yndios que andan vagos, sin tener casa ni simentera. Los quales se podrian bien comparar a los Alarabes. [...] no les da pena El dexar su casa, pueblo, ni sementera, pues no lo tienen. Antes les es mas comodo bivir solos depor si, como animales, o aves de rapiña que no se junctan unos con otros para mejor mantenerse y hallar su comida y ansi Estos nunca se junctarian si la necesidad de la guerra no les compelliese a vivir junctos» ${ }^{17}$.

17 Este documento, con el título de Tratado de los chichimecas de nueva España, se encuentra en la Real Biblioteca de El Escorial, y fue consultado y transcrito por el autor de este trabajo (véase Campos 1993: 328). 
El religioso reproduce el estereotipo del contraste cultural entre la cultura urbana y la chichimeca, en esta ocasión dando a entender que éste es común a mexicanos -se entiende aztecas, de alta cultura- y españoles. Datos ciertos desde el punto de vista de la teoría antropológica son la ausencia de agricultura, el nomadismo y el hecho de que no exista estratificación social ni instituciones estables de gobierno, más allá de la confederación por causa de la guerra, por otra parte típica de tribus segmentarias. Como indicadores del sesgo propio de los mitos de alteridad del salvaje sí hemos de citar la explícita comparación con «animales o aves de rapiña» y el término de alárabe, que posteriormente comentaremos. Naturalmente, desde el punto de vista del autor, dicho modo de vida legitima y hace necesaria la conquista y evangelización ${ }^{18}$.

Otro religioso, Francisco Cervantes de Salazar, en una obra escrita entre 1557 y 1564, nos ofrece una descripción de los chichimecas bastante cercana a la anterior:

«Hay otros indios que llaman chichimecas, que siguen la costumbre de los alárabes, no tiniendo casa ni morada cierta, ni labrando los campos de que se sustenten, manteniéndose según los tiempos, unas veces de fructa de la tierra y otras de la caza que matan, porque son muy grandes flecheros. Finalmente, desto que he dicho parescerá la nescesidad que tenían de policía y la merced grande de Dios les hizo en inviarles los españoles, y entre ellos a los religiosos y clérigos que les predicasen y los instruyesen y alumbrasen de los errores en que estaban tan contra toda razón» (Cervantes de Salazar 1971, cap. XV: 128).

Junto al uso del mismo término de alárabes, los rasgos mencionados por el autor castellano son identificables con el modelo antropológico de bandas. Destaca de nuevo, por supuesto, la interpretación de que dicho modo de vida es erróneo y contra la razón, lo que justifica y legitima su aculturación mediante la labor misionera.

Bernardino de Sahagún, por su parte, utiliza explícitamente el apelativo propio del hombre salvaje europeo -silvestre, el que vive en el bosque, lejos de la civilizaciónpara referirse a los chichimecas de cultura menos compleja. Tras ofrecer una distinción respecto a otros chichimecas «más republicanos» o integrados en la sociedad azteca, se refiere a los que llama teochichimecas...

«que quiere dezir 'del todo bárbaros', que por otro nombre se dezían çacachichimecas, que quiere dezir 'hombres silvestres', eran los que habitavan lexos y apartados del pueblo, por campos, cabañas, montes y cuevas, y no tenían casa cierta, sino que de unas partes en otras andavan vagueando y donde les anochecía, si havía cueva, se quedavan allí a dormir.» (Sahagún 1990, II, Libro X, cap. 29: 753).

El jesuita José de Acosta nos ofrece también un testimonio repetitivo, pues es sabido que, como era usual en la época, su trabajo recopila información de obras precedentes de otros religiosos, como Tovar, por lo que reproduce casi exactamente el pasaje de la obra de Durán que hemos citado anteriormente: chichimecas como «bárbaros y silvestres», «fieras» que «habitan riscos», «viviendo bestialmente sin ninguna policía, desnudos totalmente», sin mando ni dioses. La aportación explícita de Acosta

18 De hecho, «en el encabezamiento del tratado hay una declaración de intenciones por parte del autor; ahí podemos encontrar otro título con un nuevo matiz: «justicia de la guerra q[ue] se les ha hecho y haze [a los chichimecas]...»» (Campos 1993: 328, nota 32); más aún: «no es mi yntención escreuir su historia, sino tan solamente lo q[ue] toca a la justificación de la guerra» (Campos 1993: 330, nota 37). 
coincide en el fondo con otros autores ya citados, al considerar que esa indigna vida justifica la labor evangelizadora: «es necesario enseñallos primero a ser hombres, y despues a ser cristianos» (Acosta 1987, libro 7, cap. II: 438-439).

El franciscano Juan de Torquemada concluyó su Monarquía indiana en 1615. Al citar sus fuentes, menciona explícitamente a otros religiosos de su orden como Motolinía, Sahagún y Mendieta. Su referencia a los chichimecas es extensa, aunque carente de valor etnográfico. En cambio, aporta una elaboración intelectual sobre la consideración de «las primeras gentes del mundo, la barbaridad» que, citando a diversos autores antiguos como Tulio o Plutarco, le permite establecer una etapa primitiva en la que «los hombres vivían [...] por montes y campos, como salvages y bestias, [la cual] fue común a todo el linage humano» (Torquemada 1986 I, libro I, cap. XXII: 47-48). De este modo, el ejemplo de los chichimecas, que viven esparcidos por cuevas y riscos, y no en pueblos ni ciudades, así como su desnudez y vida brutal y bárbara, pueden ser explicados haciendo referencia a esa etapa primitiva común a toda la humanidad. Ese estado de barbarie o salvajismo se prolongaría hasta que gentes de mayor entendimiento comenzaran a organizar la vida en comunidad, a establecer leyes y dar noticia de dios. Esos sabios habrían luego paulatinamente extendido ese orden y policía por otros territorios, como en el caso de Italia, donde antes de la llegada del sabio rey griego Saturno, las gentes eran rudas y silvestres (Torquemada 1986 I, libro I, cap. XXII: 48-50).

La aportación de Torquemada, como la de otros evangelizadores citados aquí, incluye sin lugar a dudas a los chichimecas entre el género humano, y justifica y legitima el proceso evangelizador que habrá de permitir integrar a aquellas gentes primitivas en la sociedad civilizada y cristiana. Pero destaca la elaboración intelectual de integración de todos los pueblos y su diversidad cultural en un marco histórico común que bien podemos calificar de evolucionista: tras una fase primitiva de barbarie sucederá la extensión de la civilización, a la que el autor, claro está, dota de un sentido providencialista. En este caso, por tanto, los chichimecas no son un pueblo maligno o demoniaco, sino sencillamente primitivo.

El siguiente testimonio que revisaremos pertenece a un cronista mestizo de Tlaxcala llamado Diego Muñoz Camargo (1529?-1599). Hijo de princesa tlaxcalteca y de conquistador español, en su obra se identifica plenamente con la religión cristiana y el rey español, por lo que en su discurso no se reconocen rasgos distintos a los de los conquistadores (Velazco 1999: 13). Su explicación del término incluye una versión de su etimología:

«chichimecas, propiamente, quiere decir 'hombres salvajes' [...] aunque la derivación de este nombre procede de hombres que comían las carnes crudas y se bebían y chupaban las sangres de los animales que mataban, porque chichiliztli por 'cosa que chupa' y chichihualli es la 'teta' o la ubre. Por manera que como estas gentes mataban y se bebían la sangre, eran tenidas por una gente muy cruel y feroz, de nombre espantable y horrible, entre todas las naciones de estas partes» (Muñoz Camargo 2002: 84) ${ }^{19}$.

La coincidencia de este texto con el antes citado de Alberto Magno haciendo referencia a Cicerón (vid supra) es casi literal. Estamos pues ante una prueba fehaciente

19 La etimología no parece correcta (Santamarina 2006: 212). 
de que el mito del salvaje europeo se había instaurado en la sociedad novohispana y servía de referencia a la hora de concebir y describir a sociedades de cazadores recolectores como los chichimecas. No puede sorprender el hecho si tenemos en cuenta la importancia en la educación de la época de la retórica y el estudio de las autoridades de la edad antigua y medieval en el seno de la cultura hispano-cristiana ${ }^{20}$.

Pero en este texto, Muñoz Camargo ha ido más allá que los demás cronistas hasta ahora citados, al afirmar que los chichimecas mataban y bebían la sangre de sus presas. Quizá se trata de la «fe del converso», o más bien, del mestizo, o, como prefiere Velazco, del transculturado (Velazco 1999: 3). Este autor explica que el cronista de Tlaxcala...

«No sólo [...] construye discursivamente la realidad física del Anahuac como un edén abierto a la expoliación, sino que también se enfrasca en la construcción de la alteridad (el indígena americano) como un ser devaluado culturalmente. El espacio textual en que se escucha su particular voz confina al indígena al mundo de la 'barbarie'» (Velazco 1999: 13).

Pero sigamos leyendo a Muñoz Camargo sobre los chichimecas:

«Ha quedado este nombre de chichimecas el día de hoy ya tan arraigado que todos aquellos que viven como salvajes y se sustentan de cazas y monterías y hacen crueles asaltos y matanzas en las gentes de paz, y aquellos que andan alzados con arcos y flechas como alarbes, son tenidos y llamados chichimecas. Especialmente en los tiempos de agora son los más crueles y espantosos que jamás lo fueron, porque en otros tiempos (ha menos de cuarenta años) no mataban sino cazas y animalías fieras y silvestres, y agora matan hombres, saltean caminos y hacen grandes estragos e inauditas crueldades en los españoles y en sus haciendas y estancias, que no se pueden averiguar con ellos. Por manera que el nombre de chichimeca, que solía ser la cosa más noble que entre los naturales había, ha venido a ser y a parar, que los que llaman el día de hoy chichimecas se han de entender por hombres salteadores y robadores de caminos. Todos aquellos que son indomésticos, que habitan las tierras remotas de la Florida y la demás tierra que está por ganar y por conquistar, todos tienen este nombre de chichimecas, y esto se entiende en la lengua mexicana culhua de la Nueva España..» (Muñoz Camargo 2002: 84-85).

Además de repetir, como otros autores, el término alarbe como sinónimo de salvaje, este párrafo es interesante porque establece una distinción temporal entre los chichimecas de antaño, que se dedicaban a la caza y eran dignamente considerados, y los de la época del cronista, el siglo XVI, en que son más crueles y se les considera peligrosos salteadores de caminos. Por último, se subraya la oposición entre chichimecas y toltecas (mexicas culhuas) como propia de la lengua y cultura azteca, campo propicio pues para la instauración de la concepción de alteridad propia de los conquistadores hispano-cristianos.

20 Como muestra de lo influyente de la figura de Alberto Magno en la época, podemos citar la mención explícita que hallamos en la obra de Fernando de Alva Ixtlilxóchitl, uno de los cronistas más destacados de la época colonial. El cronista de Texcoco lo cita entre reyes y papas para datar su propia narración (Alva Ixtlilxóchitl 1977, I: 313). 


\section{Los nombres de la alteridad}

Repasaremos a continuación algunos de los términos utilizados en nuestras fuentes para designar la alteridad, la condición que ostentan aquellos que son otros.

Cuando José de Acosta da noticia de cómo los descendientes de los toltecas poblaron las mejores tierras, hace uso de un término indígena:

«los chichimecas [...] como no cogían, ni sembraban, dejaron la mejor tierra y más fértil sin poblarla, y ésa ocuparon las naciones que vinieron de fuera, que por ser gente política, la llaman Navatlaca, que quiere decir gente que se explica y habla claro, a diferencia de esotra bárbara y sin razón» (Acosta 1987, libro 7º cap. II: 439).

En este caso la oposición barbarie/civilización se establece en torno al factor lingüístico: el término náhuatl nahuatlaca significa gente que habla náhuatl, la lengua dominante en el ámbito de influencia azteca, y que etnocéntricamente se identifica como «los que hablan claro» frente a los bárbaros chichimecas, cuya cultura se considera inferior y cuya lengua es ininteligible ${ }^{21}$.

De nuevo, el estereotipo europeo parece encajar a la perfección en el estereotipo de alteridad mesoamericano, pues el término bárbaro tiene en la tradición europea ese significado etnocéntrico de expresar una alteridad que se denigra frente a la cultura propia. Bárbaros son aquellos cuya lengua es ininteligible y suena bar-bar, como nos recuerda Alberto Magno, una ya citada autoridad medieval, de nuevo mencionando a autores antiguos: «el nombre bárbarus es onomatopéyico, como dice Estrabón...» (Pagden 1988: 42).

\section{Si consultamos el término bárbaro en el diccionario histórico de Covarrubias:}

«Este nombre fingieron los griegos de la grossera pronunciación de los estrangeros, que procurando hablar la lengua griega la estragavan, estropeándola con los labios, con el sonido de barbar. [...] Después que se passó a los romanos, también ellos llamaron a los demás bárbaros, fuera de los griegos; finalmente a todos los que hablan con tosque-

21 El Vocabulario en lengua castellana y mexicana de Molina, de 1571, glosa el término nauatl como «cosa que suena bien, assi como campana» (Molina 1992: sub voce). Por su parte, Siméon reproduce esa acepción ampliándola: «Que suena bien, que produce un buen sonido, etc.; sagaz, astuto, hábil» (Siméon 1992: sub voce), y una segunda, desde el punto de vista lingüístico: «lengua mexicana, es decir, lengua armoniosa, que agrada al oído.» Por otro lado, la voz popoloca y sus derivados en la misma lengua náhuatl, viene a representar el otro término de la oposición, siendo un término equivalente, como expresión peyorativa de alteridad, a salvaje o bárbaro: «Popoloa. desperdiciar o destruyr algo [...] o escurecer la claridad grande a la pequeña. Popoloca. barbaro, hombre de otra nación y lenguaje. Popoloni. Ser tartamudo, o empedido de la lengua» (Molina 1992: sub voce). Otros ejemplos los hallamos en un texto indígena -asociado a los Anales de Tlatelolco- cuando se refiere a una supuesta conspiración de Cuauhtemoc y algunos de sus seguidores. Los conspiradores hablan de matar a los españoles, a quienes se refieren como: «esos extranjeros, esos otomíes (in tenime, yn otomin)» (Terraciano 2014: 214). Los citados son términos náhuatl de alteridad, con sentido despectivo: «tenitl adj. Extranjero, grosero; pl. tenime. Se daba este nombre a las tribus salvajes que habitaban en provincias alejadas, como las de Couixco, Chilapan, etc., que no hablaban el nahuatl; estaban a menudo en guerra con los aztecas y para éstos era un gran mérito vencerlos, por lo que nombraban capitán a quien hubiere capturado a seis, siete o diez de aquellos enemigos (Sah.). (Siméon 1992: sub voce). El término otomí se usa en sentido similar: «otomitl s.; pl. otomi. Tribus salvajes que habitaban en cavernas y vivían del producto de la caza; a partir del siglo xv reconocieron la autoridad de los príncipes chichimecas de Acolhuacan, sin perder completamente su primitivismo» (Siméon 1992: sub voce). También, popoloca se usa en el mismo sentido en náhuatl: «gruñir, murmurar, hablar entre dientes; ser tartamudo, hablar una lengua bárbara, extranjera» (Siméon 1992: sub voce). 
dad y grossería llamamos bárbaros y a los que son inorantes sin letras, a los de malas costumbres y mal morigerados, a los esquivos que no admiten la comunicación de los demás hombres de razón, que viven sin ella, llevados de sus apetitos, y finalmente, los que son desapiadados y crueles.» (Covarrubias 1977 [1611]: sub voce).

Vemos por tanto que la construcción ideológica de la alteridad va más allá de constatar la diferencia en el lenguaje, asociando una serie de valoraciones negativas como ignorancia, tosquedad, grosería, falta de razón, crueldad e incapacidad de comunicación a aquellos que no comparten la lengua del observador. Son todas características que hemos visto integradas en la amplia y dilatada corriente mitológica europea del salvaje.

Pero los cronistas utilizan también otro término expresivo de dichos mitos de alteridad. Hemos citado ya aquí a Gonzalo de las Casas o a Diego Muñoz Camargo calificando a los chichimecas de alarbes o alárabes. Se trata de un rasgo muy expresivo del concepto de alteridad que se había desarrollado en la España del siglo XVI. El término se refiere a los árabes, con un sentido peyorativo de la alteridad, por lo que en el diccionario de la RAE encontramos una segunda acepción del término alarbe: «hombre inculto o brutal» muy en consonancia con los textos que hemos revisado en relación con el concepto de chichimeca como reedición del mito del salvaje.

Otro término, muy en consonancia con el anterior, viene a subrayar la especificidad del caso hispano a la hora de construir su propia imagen etnocéntrica de la alteridad:

«Algarabía (Del ár. hisp. al'arabíyya, y este del ár. clás. 'arabiyyah). 1. f. Lengua árabe. 2. f. coloq. Lengua o escritura ininteligible. 3. f. coloq. Gritería confusa de varias personas que hablan a un tiempo. 4. f. coloq. p. us. Manera de hablar atropelladamente y pronunciando mal las palabras» (DRAE, sub voce).

La lengua árabe, por tanto, se identifica - de un modo similar a como se interpreta el término bárbaro - con la confusión, con el griterío ininteligible, con la imposibilidad de comunicación, que es uno de los atributos definitorios del salvaje.

Así que estos dos términos tan castellanos, alárabe y algarabía nos dejan ver que la concepción hispana de alteridad se construyó sobre la cultura opuesta que se reconocía en los musulmanes.

Para demostrar que esa concepción de alteridad cruzó los mares y se instaló en la América hispana, nos acercaremos a otra de las más importantes y conocidas fuentes novohispanas sobre la cultura azteca.

El Códice Mendoza es un documento redactado durante la etapa colonial temprana en Nueva España -quizá alrededor de 1542 (Batalla 2007: 11)- con objeto de informar al rey español de la historia, costumbres, conquistas y tributos de los aztecas. Para su redacción se utilizaron fuente indígenas anteriores, como la llamada Matrícula de Tributos. Al reproducir pictografías y glifos de tradición indígena se hizo necesario el concurso de un glosador, que iba anotando en castellano el significado de algunos glifos y escenas de acuerdo con las explicaciones de sus informantes indígenas. Pero el dicho escribiente encargado de las glosas no debió de trabajar en las mejores condiciones, pues al final del documento se sintió impulsado a incluir la siguiente nota de descargo: 
Figura 4: Códice Mendoza, fol.61r (detalle). Transcripción de las glosas, de izquierda a derecha: «Mozo de quince años que su padre lo entrega al alfaquí mayor para que lo reciba por alfaquí. Tlamacazqui, que es alfaquí mayor. Mezquita que llamaban calmecac» (Códice Mendoza 1979: 173).

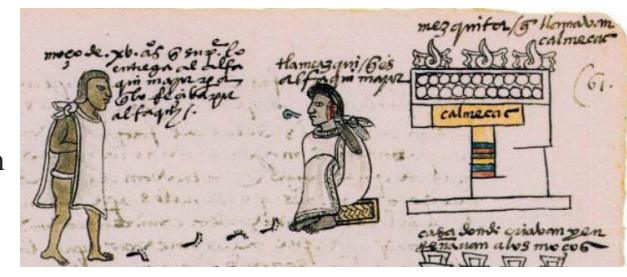

«El estilo grosero e interpretación de lo figurado en esta Historia, supla el lector, porque no se dio lugar al interpretador de ningún vagar, $\mathrm{y}$, como cosa no acordada ni pensada, se interpretó a uso de proceso. Asímismo, en donde van nombrados alfaquí mayor y alfaquí novicio, fue inadvertencia del interpretador poner tales nombres que son moriscos. Hase de entender por alfaquí mayor, sacerdote mayor, y por el novicio, sacerdote novicio; y donde van nombrados mezquitas hase de entender por templos» (Códice Mendoza 1979: fol. 71v).

Efectivamente, la presión a la que se ve sometido el glosador es, en este sentido, una circunstancia afortunada para nosotros, pues, apremiado por la pronta partida de la flota, utiliza términos propios de la cultura árabe para referirse a aspectos de la cultura azteca, como los que designan a los sacerdotes o los templos (Figura 4). Con ello deja ver la asociación más o menos inconsciente que, desde el punto de vista de la cultura española, se establece entre el nuevo referente de alteridad y el tradicional, siempre en contraste con la cultura hispano-cristiana. Una muestra más de la «naturalidad» con la que las representaciones de la alteridad integradas en la cultura hispana se instalaron en el Nuevo Mundo ${ }^{22}$.

Por otra parte, estos casos referidos a la identidad castellana frente a la cultura musulmana ilustran bien el hecho paradójico de que la construcción ideológica de la alteridad consiste en negar explícitamente algo que implícitamente nos es propio, tal y como expresa la metáfora del espejo en el título de la obra de Bartra: la identidad castellana se afirma negando una de sus principales raíces culturales ${ }^{23}$.

22 La identificación del indio con el musulmán, como referentes de la alteridad hispana, es explícita en ocasiones: «Comenzaron las conquistas de los indios acabadas la de moros, porque siempre guerreasen españoles contra infieles» (López de Gómara 1987: 17). Además, las primeras experiencias de «observación etnográfica» de los españoles en América tuvieron lugar en las Antillas, donde ya vemos aplicar esa traslación del sujeto de alteridad: «Areito es como zambra de moros» (López de Gómara 2011: 62). El mismo autor nos ofrece otro testimonio preñado de etnocentrismo que amalgama sin reparos diversos elementos relacionados con el concepto de alteridad de los conquistadores. Se trata de un epígrafe que relata la expedición de Alvarado al Perú: «Hallaron muchas esmeraldas y muchos hombres sacrificados, ca son los de allí muy crueles, idólatras, viven como sodomitas, hablan como moros y parecen judíos» (López de Gómara 2011: 218). Por otro lado, es necesario tener en cuenta que este autor es un español que jamás pisó el continente americano, aunque por supuesto maneja fuentes generadas en América. Quizá ello explique sus explícitos paralelismos entre los «otros» tradicionales peninsulares y los nuevos «otros» americanos.

23 Los discursos de identidad y de alteridad se necesitan mutuamente para existir (Barabas 2000: 9-10), pues «el sujeto se reconoce a sí mismo reconociendo al otro» (Adorno 1988: 66). Pese a que los europeos lo rechazan como antagónico a sus propios valores, «paradójicamente, el salvaje es una de las claves de la cultura occidental» (Bartra 1992: 190). Como ha escrito LéviStrauss, «la paradoja del relativismo cultural [...consiste en que...] en la misma medida en que pretendemos establecer una discriminación entre culturas y costumbres, nos identificamos más con aquellas que intentamos negar» (Levi-Strauss 1996: 99). Volviendo a Stevenson: Jekyll y Hyde no dejan de ser la misma persona. 


\section{Conclusiones}

La cuestión general que planteamos, y en la que se ha inscrito este trabajo, es si acaso -o más bien hasta qué punto- los mitos de alteridad de la cultura europea han influido en nuestro conocimiento de las culturas indígenas americanas. Ello nos lleva a plantear un acercamiento crítico a todas las fuentes -ya sean históricas o etnológicas, antiguas o modernas- para tratar de depurar la influencia de dichos mitos de alteridad en las versiones que manejamos para acceder al conocimiento de las culturas indígenas americanas.

En concreto, en el presente trabajo se ha demostrado, a través del análisis de una serie de fuentes disponibles para el ámbito novohispano, que las descripciones que nos ofrecen los cronistas sobre los pueblos genéricamente denominados chichimecas tienen un escaso valor etnográfico y muestran sin lugar a dudas la influencia de los mitos de alteridad de tradición europea que, desde tiempos muy antiguos, crearon el mundo mítico del salvaje, con sus múltiples variantes, para afirmar la propia identidad refiriéndose a pueblos exóticos y culturalmente lejanos, ya fueran reales o imaginados.

Las descripciones ofrecidas por los cronistas reproducen en buena medida el estereotipo del salvaje como ser carente de los rasgos más característicos de la civilización: agresivos y belicosos, sin organización social ni política, sin asentamiento fijo, sin agricultura, sin ciudades, sin religión y sin lenguaje inteligible, e incluso comiendo la carne cruda y bebiendo la sangre de sus presas. Una serie de epítetos, además, contribuyen a reforzar la idea de que se trata de gentes semihumanas, más cercanas al mundo animal que el resto de los humanos: bestiales, brutales, feroces, salvajinos, agrestes, silvestres, como perros o aves de rapiña...

Sin embargo, consideramos que la caracterización del chichimeca como salvaje semihumano es superficial, y no resistió un contacto más directo y continuado entre los observadores y los indígenas. Ninguno de los autores mencionados niega la condición humana de los chichimecas, sino que, más bien, dan a entender que se trata de un estadio cultural, por lo que son susceptibles de ser civilizados, de ser evangelizados, tal y como, por ejemplo, expresan explícitamente Acosta o Torquemada ${ }^{24}$.

Si bien la caracterización del chichimeca como salvaje, en primer lugar, legitima e impulsa a la «pacificación» por las armas, en segunda instancia sirve también para afirmar la necesidad de evangelización, de integración en la sociedad hispano-cristiana dominante. En realidad, no podemos dejar de reconocer que se trata de dos fases de un mismo amplio proceso de aculturación, de dominación colonial.

Por otro lado, una conclusión clave de nuestro estudio, que atañe al proceso de proyección de los propios mitos de alteridad sobre otros pueblos, se refiere al modo

24 Respecto a nuestros cronistas, la influencia de los mitos de alteridad europeos que advertimos en sus textos no nos impide reconocer que hicieron una contribución invaluable para el conocimiento de los pueblos indígenas americanos, que muchas veces ha sido calificada de protoantropológica (Santamarina 2006: 186187). Si nos fijamos por ejemplo en Sahagún -por nombrar al más señalado-, hallamos que puso en práctica un método de trabajo protoetnográfico a base de entrevistas, selección de informantes y consideración global de la cultura que no puede dejar de considerarse antecedente directo de la moderna antropología (Graulich 1990: 46; Baudot 2001: 159). 
en que la mente humana asume el conocimiento de lo diferente, de cómo los pueblos asumen el contacto con una realidad que previamente desconocían.

En este sentido, hemos constatado que la presencia de los mitos de alteridad del salvaje europeo en la mente de los observadores novohispanos mediatizó su acceso y comprensión de las novedades americanas en muy diversos campos -como el geográfico o biológico-, pero especialmente en lo cultural.

De este modo procedían a la hora de interpretar las sociedades indígenas americanas más primitivas o simples -las que hoy la ciencia antropológica clasifica como bandas o tribus de cazadores recolectores- reproduciendo las tradiciones de alteridad heredadas históricamente en torno al mito del salvaje y anteponiéndolas a una realidad cultural que, en realidad, no conocían bien, pues por el estado de guerra que se mantenía con dichos grupos chichimecas, el conocimiento de nuestros autores es siempre lejano e indirecto.

Lejos de ser, por tanto, muestra de irracionalidad, el acercamiento intelectual novohispano a dichas novedades americanas se veía mediatizado por el bagaje cultural, en el sentido más amplio, de los observadores. Y hay razones para creer que este es un rasgo universal: para enfrentarse a lo desconocido la mente humana necesita establecer analogías con lo conocido, encontrar un patrón común que permita asimilarlo de alguna forma a la experiencia previa, al menos inicialmente, para, con posterioridad, ir estableciendo las diferencias entre lo conocido y lo novedoso ${ }^{25}$. Tal y como John Elliott (1990: 34) ha escrito:

«Es difícil rechazar la impresión de que los europeos del siglo XVI, como los chinos en las tierras del sur, veían con demasiada frecuencia lo que querían ver. Y ello no debía ser razón para sorprenderse o para burlarse, ya que muy bien puede ser consecuencia de que la mente humana tiene una innata necesidad de apoyarse en los objetos que les son familiares y en las imágenestipo para adaptarse al choque con lo desconocido».

Desde el campo de la historia de la ciencia, Thomas S. Kuhn nos muestra que, en efecto, el proceso de aprehensión de lo hasta entonces desconocido parece requerir el apoyo de lo conocido:

«En la ciencia, [...] la novedad surge sólo dificultosamente, manifestada por la resistencia, contra el fondo que proporciona lo esperado. Inicialmente, sólo lo previsto y lo habitual se experimenta, incluso en circunstancias en las que más adelante podrá observarse la anomalía. Sin embargo, un mayor conocimiento da como resultado la percepción de algo raro o relaciona el efecto con algo que se haya salido antes de lo usual. Esta percepción de la anomalía abre un periodo en que se ajustan las categorías conceptuales, hasta que lo que era inicialmente anómalo se haya convertido en lo previsto. En ese momento, se habrá completado el descubrimiento» (Kuhn 1990: 109-110) ${ }^{26}$.

25 Elliott (1990: 31) cita a Humboldt para expresar de modo conciso esa primera fase de observación: «Ver... no es observar, sino comparar y clasificar». Como ejemplo de que también los aztecas establecieron comparaciones a partir de lo conocido cuando hubieron de asumir las nuevas realidades venidas de Europa, podemos citar que denominaron mazatl a los caballos de los españoles, asimilándolos a los ciervos que ellos ya conocían.

26 Este autor, además, alude a una serie de experimentos psicológicos que parecen confirmar en el proceso de observación la proyección por parte del observador de los modelos cognoscitivos propios, y la dificultad de reconocer las anomalías que no respondan a esas concepciones preconcebidas. Los psicólogos expusieron 
Así que, como decía Elliott, vemos lo que esperamos ver, porque es nuestro bagaje cultural -lo conocido- lo que nos sirve de marco de referencia para interpretar los estímulos que percibimos, y sólo tras un proceso más o menos dificultoso, llegamos a reconocer las diferencias o a cuestionar nuestros viejos paradigmas.

De nuevo recurrimos a Elliott, cuando se refiere a cómo los prejuicios culturales iniciales fueron superándose gradualmente:

«La verdadera prueba viene después [de la etapa del encuentro], con la capacidad de abandonar el lazo de unión entre lo desconocido y lo conocido. Algunos europeos, y especialmente aquellos que permanecieron mucho tiempo en las Indias, pasaron con éxito esta prueba. Ellos mismos fueron dándose cuenta cada vez más de la enorme diferencia existente entre la imagen y la realidad, y esto les obligó a abandonar gradualmente sus ideas prefabricadas y sus prejuicios heredados. América era un mundo nuevo y un mundo diferente; $y$ este hecho se impuso con una fuerza abrumadora sobre los que llegaron a conocerlo» (Elliott 1990: 34).

A nuestro entender, el éxito en completar el proceso de conocimiento y de integración en el saber global -tras la observación, la descripción, la difusión y la comprensión (Elliott 1990: 31)- es difícilmente mesurable ${ }^{27}$. Sin duda es cierto que la América Colonial española tuvo un éxito relativo a la hora de integrar a los indígenas en sus estructuras, pero no lo es menos que los mitos de alteridad, lejos de desaparecer por ello, siguieron adaptándose a diferentes contextos a lo largo de la historia, de formas a veces sutiles y otras veces mucho más evidentes.

Por otra parte, los mitos de alteridad europeos en torno a la oposición entre salvajismo y civilización pudieron superponerse sobre una estructura ideológica preexistente en Mesoamérica, ya establecida en la tradición indígena, que oponía a toltecas y chichimecas. Esto nos permite una vez más constatar que, a menudo, las sociedades expansionistas se valen de la reutilización de estructuras de dominación preexistentes para instaurar su nuevo sistema de dominación (Santamarina 2006: 36). En el caso de la colonización española, no cabe duda de que su éxito a la hora de instaurarse en Mesoamérica o los Andes debe mucho al hecho de que en esas áreas existían previamente estados complejos que ofrecían a los españoles una serie de estructuras sociales, políticas, demográficas y de producción, pero también ideológicas, para reutilizarlas en la instauración del sistema colonial hispano. Los mitos de alteridad han de entenderse también en este sentido, pues los de origen europeo encajaron con relativa facilidad con los preexistentes: la oposición entre la tradición de alta cultura mesoamericana y el resto de pueblos de aquella área, expresada con los etnónimos contrapuestos de tolteca o nahuatlaca frente a chichimeca, popoloca o nonoalca, viene a ser expresada, en el mundo europeo y colonial, como civilización y cristianismo

a una serie de personas a estímulos conocidos -cartas de la baraja-, que reconocían, incluso cuando se introdujeron naipes anómalos, que eran generalmente tomados por normales (Kuhn 1990: 108). En relación a tal mecanismo, y volviendo a la cuestionable eficacia de los testigos de "vista de ojos», desde la psicología criminal actual se afirma que entre los múltiples factores incidentes en la codificación de un suceso por parte de un testigo estarían las «expectativas, prejuicios y estereotipos» (Otín del Castillo 2009: 88). Como dijo el poeta: «lo que vemos no es lo que vemos, sino lo que somos».

27 En parte la respuesta a ese reto, por supuesto, está en el desarrollo de la antropología como ciencia, cuyos primeros pasos ya sabemos que los dieron algunos de los autores españoles aquí citados en América, pero habría que preguntarse por la repercusión social de dichos avances. 
frente a barbarie o salvajismo. Por tanto, la prolongación de las alteridades tradicionales mesoamericanas en el mundo colonial facilitó la instauración de los mitos de alteridad importados desde el viejo mundo. $Y$ todos esos componentes complejos son los que integran la sociedad novohispana y, por lo tanto, están en nuestras fuentes.

El estudio de los mitos de alteridad de origen europeo, aquí circunscrito a una serie de fuentes coloniales, nos ofrece una perspectiva de estudio de gran interés y amplitud. Más allá de la relativamente constatable reproducción de historias bíblicas o de creencias medievales, los mitos de alteridad europeos, lejos de extinguirse con el desarrollo de la ciencia, han seguido viviendo entre nosotros, como parte tanto de la cultura dominante como de las subalternas, adaptándose y diversificándose a través de diferentes contextos: la literatura, el cine, pero también las creencias populares o los conflictos étnicos y de clase.

Es amplísimo el escenario histórico, más allá del fin del periodo colonial europeo en América, en el cual puede constatarse la presencia de los mitos de alteridad emparentados con el salvaje europeo, de forma a veces explícita, incluso bajo la forma extrema del racismo, formando parte de una ideología que legitima la marginación e incluso el exterminio de pueblos culturalmente diferentes. Otras veces, sin embargo, adoptando formas mucho más sutiles e integradas en la cultura que requieren de un análisis mucho más profundo. El siglo XIX, origen inmediato de la sociedad occidental contemporánea, nos ofrece, incluso circunscribiéndonos al continente americano, abundante material para constatar el desarrollo de los mitos de alteridad europeos, donde el mito del salvaje ha seguido existiendo bajo diversas formas, ya sea en la forma agresiva y racista legitimadora del genocidio o en la más amable por paternalista pero también «inferiorizante» del indigenismo (Barabas 2000); desde el temor a los indios belicosos hasta el afán coleccionista de los últimos vestigios de la «vida primitiva».

La Historia de la Antropología no deja también de ser un campo propicio para preguntarnos si acaso los propios antropólogos no han caído ellos mismos en la tentación de proyectar sus propios mitos de alteridad, y si acaso el mito del salvaje no ha encontrado acomodo subrepticio en las monografías etnográficas. La gran cuestión que queda abierta para el análisis es si acaso la propia Historia de la Antropología no requiere también de un enfoque [auto]crítico capaz de reconocer y depurar en lo posible la influencia de estos u otros mitos de alteridad, desde los inicios de la ciencia antropológica hasta la actualidad.

\section{Referencias bibliográficas}

Acosta, José

1987 Historia natural y moral de las Indias. Edición, introducción y notas de José Alcina Franch. Crónicas de América 34. Madrid: Historia 16.

AdORno, Rolena

1988 «El sujeto colonial y la construcción cultural de la alteridad». Revista de crítica literaria latinoamericana 28 ( $2^{\circ}$ semestre): 55-68. 
Alva IxtLilxóchith, Fernando de

1977 Obras históricas, 2 vols. Edición, estudio introductorio y apéndice documental de Edmundo O'Gorman. México DF: UNAM.

BARABas, Alicia M.

2000 «La construcción del indio como bárbaro: de la etnografía al indigenismo». Alteridades 19: 9-20.

BARLOW, Robert H.

1990 «La Crónica X: versiones coloniales de la historia de los mexica-tenochca», en Obras de Robert H. Barlow, Vol. 3: Los mexicas y la Triple Alianza, Jesús Monjarás-Ruiz, Elena Limón y María de la Cruz Paillés H., eds., pp. 13-32. México DF y Puebla: INAH, UDLA.

BARTRA, Roger

1992 El salvaje en el espejo. México DF: Ediciones Era.

Batalla Rosado, Juan José

1994 «Datación del Códice Borbónico a partir del análisis iconográfico de la representación de la sangre». Revista Española de Antropología Americana 24: 47-74.

2007 «"Matrícula de tributos' y 'Códice Mendoza': la autoría de un mismo 'maestro de pintores' para los folios 6-R a 11-V del primero y la totalidad del segundo». Anales del Museo de América 15: 9-20.

BAUDOT, Georges

2001 «Los precursores franciscanos de Sahagún del siglo XIII al siglo XVI en América». Estudios de Cultura Náhuatl 32: 159-173.

Bestard, Joan y Jesús Contreras

1987 Bárbaros, paganos, salvajes y primitivos. Una introducción a la Antropología. Barcelona: Barcanova.

CAmpos y Fernández de Sevilla, F. Javier

1993 Catálogo del Fondo Manuscrito Americano de la Real Biblioteca del Escorial. Madrid: Ediciones Escurialenses.

Cervantes de Salazar, Francisco

1971 Crónica de la Nueva España, 2 vols. Madrid: Ediciones Atlas.

Códice Chimalpopoca

1992 Códice Chimalpopoca. Anales de Cuauhtitlan y Leyenda de los soles. Traducción, introducción y notas de Primo Feliciano Velázquez. México: Instituto de Investigaciones Históricas, UNAM.

Códice Mendoza

1979 Códice Mendocino. Edición de José Ignacio Echeagaray. México: San Ángel Ediciones.

Colón, Cristóbal

1991 Los cuatro viajes del almirante y su testamento. Madrid: Espasa-Calpe.

Contel, José

2000 «Visiones paradisíacas. Extrañas analogías entre 'Tlallocan’ y 'Paraíso Terrenal' en la Historia General de las cosas de la Nueva España de Fray Bernardino», en Fray Bernardino de Sahagún y su tiempo, Jesús Paniagua y María Isabel Viforcos, eds., pp. 617-630. León: Universidad de León. 
Covarrubias, Sebastián de

1977 Tesoro de la lengua castellana o española. Madrid: Turner.

DíAz del CASTillo, Bernal

1982 Historia verdadera de la conquista de la Nueva España. Madrid: Instituto «Gonzalo Fernández de Oviedo», C.S.I.C.

DURÁN, Diego

1984 Historia de las Indias de Nueva España e Islas de Tierra Firme, 2 Vols. Edición de Ángel María Garibay. México DF: Porrúa 36 y 37.

ELLIOTT, John H.

1990 El Viejo Mundo y el Nuevo (1492-1650). Madrid: Alianza Editorial.

GraULICH, Michel

1990 Mitos y rituales del México Antiguo. Madrid: Istmo.

KuHn, Thomas S.

1990 La estructura de las revoluciones cientificas. Madrid: Fondo de Cultura Económica.

LÉVI-STRAuSs, Claude

1969 Las estructuras elementales del parentesco. Barcelona: Paidós Básica, 3.

1996 «Raza e historia», en Lecturas de antropología social y cultural: la cultura y las culturas, Honorio M. Velasco Maillo, ed., pp. 95-128. Madrid: Universidad Nacional de Educación a Distancia.

López Austin, Alfredo y Leonardo LóPEz LujáN

1999 Mito y realidad de Zuyuá. Serpiente Emplumada y las transformaciones mesoamericanas del Clásico al Posclásico. México DF: El Colegio de México y Fondo de Cultura Económica.

LóPEZ DE GómARA, Francisco

1987 La conquista de México. Edición, introducción y notas de José Luis de Rojas. Crónicas de América 36. Madrid: Historia 16.

2011 Historia General de las Indias. Barcelona: Linkgua.

MARÍn PINA, Ma Carmen

1998 «Introducción», en Primaleón. Madrid: Centro de Estudios Cervantinos.

Molina, Fray Alonso de

1992 Vocabulario en lengua castellana y mexicana y mexicana y castellana. México DF: Porrúa.

Moore, John H.

2004 Los cheyenes. Barcelona: Ariel.

Motolinía, Toribio de Benavente

1985 Historia de los indios de la Nueva España. Edición e introducción de Claudio Esteva Fabregat. Crónicas de América 16. Madrid: Historia 16.

Muñoz CAmargo, Diego

2002 Historia de Tlaxcala. Crónicas de América 42. Madrid: Dastin.

Muñoz Morán, Óscar

2008 «Salvajes, bárbaros y brutos. De la Grecia clásica al México contemporáneo». Liminar. Estudios Sociales y Humanísticos 6 (2): 155-167. 
OTín del CASTillo, José María

2009 Psicología criminal. Técnicas aplicadas de intervención e investigación policial. Valladolid: Lex Nova.

PAGDEN, Anthony

1988 La caida del hombre natural. El indio americano y los orígenes de la etnología comparativa. Madrid: Alianza Editorial.

SAHAGún, Bernardino de

1990 Historia General de las cosas de la Nueva España, 2 vols. Edición de Juan Carlos Temprano. Crónicas de América 5. Madrid: Historia 16.

Santamarina Novillo, Carlos

2006 El sistema de dominación azteca: el Imperio Tepaneca. Serie Historia 11. Madrid: Fundación Universitaria Española.

SimÉON, Rémi

1992 Diccionario de la lengua náhuatl o mexicana, 9a edición. América Nuestra 1. México DF: Siglo XXI.

Soustelle, Jacques

1993 La familia otomí-pame del México central. México DF: Fondo de Cultura Económica.

TERraciano, Kevin

2014 «Narrativas de Tlatelolco sobre la Conquista de Mexico». Estudios de Cultura Náhuatl 47 (enero-junio): 211-235.

ToDorov, Tzvetan

1992 La conquista de América. El problema del otro. México DF: Siglo XXI.

TORQUEMADA, Juan de

1986 Monarquía indiana, 3 vols. México DF: Porrúa.

VELAZCO, Salvador

1999 «Historiografía y etnicidad emergente en el México colonial: Fernando de Alva Ixtlixochitl, Diego Muñoz Camargo y Fernando Alvarado Tezozomoc». Mesoamérica 38: 1-32. 